\title{
Особливості організації дистанційного навчання як форми проведення уроків фізичної культури
}

\author{
Микола Шаповалов \\ Руслана Сушко
}

Київський університет імені Бориса Грінченка, Київ, Україна

\begin{abstract}
Мета: дослідити сучасні підходи до дистанційного навчання на уроках фізичної культури у закладах загальної середньої освіти.

Матеріал і методи: застосовано аналіз науково-методичної літератури та інформативних даних мережі Інтернет; анкетування за допомогою google-форми; методи математичної статистики, організовано анкетування 95 учнів загальноосвітніх шкіл міст Києва і Білої Церкви.

Результати: проаналізовано сучасний стан питання щодо організації і проведення дистанційного навчання. Визначено, що організація уроків фізичної культури носить переважно формальний характер, є малоефективною $і$ повинна зазнати кардинальних змін, не може бути альтернативою практичним заняття в спортивному залі, а лише їх доповненням. Оцінка задоволеності учнями проведенням уроків фізичної культури надала обгрунтовані підстави зрозуміти проблеми організації дистанційних уроків, необхідність змін у підходах до навчання фахівців фізичного виховання, що саме доцільно додати в організації уроків фізичної культури під час дистанційного навчання задля ефективної відповідності вимогам та потребам сучасного школяра.

Висновки: виявлено, що рівень задоволеності учнів проведенням уроків фізичної культури в умовах карантинних обмежень, напряму залежить від зацікавленості, відповідальності, професіоналізму наставника та активного зворотного зв 'язку учень-вчитель. Відсутність зазначених складових нівелює гармонійний розвиток школяра і провокує негативні наслідки. З'ясована переважна зацікавленість учнів у отриманні знань, вмінь та навичок, носіями яких є вчитель фізичної культури.
\end{abstract}

Ключові слова: фізична культура, урок, дистанційне навчання, коронавірус.

\section{Вступ}

Урок фізичної культури є важливою та однією з основних складових навчального процесу в загальноосвітніх школах, адже фізична культура має бути невід'ємною частиною життя кожного учня [1, 4]. Через економічний стан багатьох сімей України і відсутню спроможність оплати спортивних секцій, через небезпеку тривалого перебування дітей на прибудинкових спортивних майданчиках, для багатьох школярів уроки фізичної культури є усамітненою можливістю гармонійного фізичного розвитку [2]. Сучасність у період великої світової трагедії, що має назву «пандемія коронавірус - COVID-19» диктує свої умови організації проведення уроків фізичної культури у школі під час навчального процесу [3, 6, 8]. Через особливості карантинних обмежень шкіл і міст України обґрунтовану стурбованість фахівців викликають питання дистанційного процесу організації та проведення уроків фізичної культури, що зазнають значну кількість перешкод і заважають учням системно отримувати відповідні віку і рівню підготовленості необхідні фізичні навантаження у спортивній залі $[4,5,9]$. Проблемність існуючої ситуації посилюють близькість відвертого провалу освітнього процесу на уроках фізичної культури у дистанційному форматі, невизначеність кінцевого терміну дистанційного навчання і висока вірогідність повторення локдаунів і, як наслідок, прогнозовані негативні наслідки погіршення загального стану здоров'я школярів $[5,6]$.

Фахівці, які одними з перших представили результати власних досліджень з зазначеної тематики, підкреслюють необхідність уваги до викладання фізичного виховання, врахування особливих підходів і творчий пошук шляхів реалізації можливостей фізичної активності у дистанційному форматі [7, 10].

Низка спеціалістів галузі фізичної культури і спорту, проаналізувавши стан питання дистанційної освіти, зазначає потребу у ефективному навчанні з огляду на можливу затребуваність змішаного навчання у майбутньому $[7,9-11]$.

Питання дистанційного навчання з урахуванням досвіду роботи вчителів і учнів, що отримали розуміння і можливість порівняння особливостей проведення уроків фізичної культури у звичній та дистанційній формах $є$ актуальними на сьогодні, потребують різностороннього вивчення, активного дискусійного розгляду науковців і методичних пропозицій практиків.

Мета дослідження: дослідити сучасні підходи до дистанційного навчання на уроках фізичної культури у закладах загальної середньої освіти. 


\section{СЛОБОЖАНСЬКИЙ НАУКОВО-СПОРТИВНИЙ ВІСНИК}

\section{Матеріал і методи дослідження}

Контингент дослідження: 95 учнів різних шкіл міст Києва і Білої Церкви надали власну суб'єктивну оцінку їх дистанційному навчанню та висловили пропозиції щодо покращення освітнього процесу.

Організація дослідження: охарактеризовано сучасний стан освітнього процесу на уроках фізичної культури у закладах середньої освіти, за допомогою анкетування за сформованою google-формою «Анкета для перевірки задоволеності учнями проведенням уроків фізичної культури під час дистанційного навчання» (https:// forms.gle/mT5h39yhB5iMijxo8) з'ясовано переваги та слабкі сторони дистанційного навчання на уроках фізичної культури, що проведені в умовах карантинних обмежень. 20 питань анкети містили чотири відповідні блоки:

- стосовно особистості учня (5 питань);

- стосовно особистості вчителя (5 питань);

- стосовно організації навчання(5 питань);

- стосовно якості навчання, викладання та сприйняття (5 питань).

Окрім зазначених блоків, запропоновано відкрите питання для визначення можливих форм покращення викладання на думку респондентів, які стали безпосередніми учасниками дистанційного освітнього процесу під час вимушених коректив на дистанційних уроках фізичної культури, внесених пандемією.

Методи дослідження: аналіз науково-методичної літератури та інформативних даних мережі Інтернет; анкетування за допомогою google-форми; методи математичної статистики.

\section{Результати дослідження}

За допомогою проведеного анкетування визначено особливості роботи фахівців під час дистанційного навчання, проаналізовано методи та засоби, що застосовувалися, узагальнено ставлення основних учасників освітнього процесу і їх досвід, отриманий в умовах пандемії коронавірусу COVID-19.

Перше питання анкети стосовно відчуття учня «повноцінним учасником навчального процесу на уроках фізичної культури під час дистанційного навчання» дозволило з'ясувати, що лише близько 22 \% школярів активно співпрацюють з вчителем в умовах, що склалися. $27 \%$ - схильні вважати, що скоріше залучені у процес, проте учні, що зазначили відповіді «категорично ні, скоріше ні і важко відповісти» складають загалом більшість. Якщо учень не відчуває задоволення від роботи на уроках фізкультури, на вирішення завдань оздоровчої, виховної і навчальної спрямованості на високому рівні підстави розраховувати відсутні.

У другому питанні анкети розкривається сутність мотивації та відповідальності учнів до уроків фізичної культури під час дистанційного навчання у порівнянні з заняттями у спортивній залі. Відповіді дозволили з'ясувати, що близько 15 \% учнів абсолютно з відповідальністю ставляться до проведення уроків дистанційно. 22 \% школярів вважають, що все ж вони мають ту саму відповідальність і мотивацію до уроків дистанційно, як і під час очних занять. Важливо, що більшість зазначили відповідями відмову, показавши низький рівень позитивних показників.

Третє питання мало зміст «чи відчувають діти ефект від проведених занять» і у відповідях є певна широка лінія розмежування, адже близько 45 \% учнів або абсолютно точно відчули, або вважають, що відчули ефект від занять фізичною культурою під час дистанційного навчання, а інші 45 \% навпаки, що в таких уроках немає сенсу, й лише близько 10 \% не змогли визначитись. Відповіді на це питання підкреслюють можливість ефекту від занять лише при повній мотивації та взаємній відповідальності.

У четвертому питанні розглянуто свідоме ставлення учнів до уроків фізичної культури під час дистанційного навчання. Відповіді «абсолютно так, скоріше так» показали близько 46 \% опитаних, що в першу чергу є невеликою різницею з негативним результатом і свідчить, що фактично лише кожен 2-гий з опитаних учнів свідомий у навчанні під час дистанційних уроків. Близько 54 \% школярів відповіли негативно, що розкриває неефективну сутність сучасного дистанційного навчання.

П’яте питання визначило особливості власної потреби учнів в уроках фізичної культури під час вимушеного карантину. 3'ясовано, що лише 40 \% респондентів вважають їх потрібними, а близько 60 \% у різних формах спростували їх важливість, що свідчить про формальність і отриманий негативний досвід.

Шосте питання про «високий рівень відповідальності вчителя під час проведення уроків фізичної культури в дистанційному форматі» відкрило блок питань «стосовно особистості вчителя». З'ясовано, що близько $41 \%$ школярів оцінили як «високий рівень відповідальності» роботу вчителя, а 59 \% учнів відповіли «категорично ні, скоріше ні, важко відповісти». Більшість зазначили байдужість вчителя до проведення уроків фізичної культури, а отже заняття такого формату не приносять результату, а це призводить до зниження відповідальності учнів у ставленні до навчання і власного здоров'я.

У сьомому питанні визначено думку школярів стосовно доцільності проводити уроки фізичної культури під час дистанційного навчання, якщо у вчителя відсутні достатні навички комп ютерної грамотності. Відповіді «абсолютно так, скоріше так» надали близько 45 \% респондентів і цей результат є позитивним, адже учні вважають важливими уроки фізичної культури у будь-якому форматі. Проте, більшість школярів близько 55 \%, оцінивши ситуацію негативно, продемонстрували вимогу до вчителя відповідну сучасним тенденціям розвитку школи, необхідності вдосконалення у напрямку комп'ютерних технологій і запиту до підвищення кваліфікації вчителів.

Зміст восьмого питання містив відчуття учнями повноцінності прояву професійних здібностей їх наставника. 58 \% респондентів вважають, що прояви професійних здібностей їх вчителя неповноцінними, відповівши «категорично ні, скоріше ні, важко відповісти», а 42 \% учнів відповіли “скоріше так, абсолютно так», в яких зазначено багатогранність прояву професіоналізму. Результати дослідження думок з зазначеного питання формують загальну сутність проблеми практичного спрямування уроків і складність повноцінного прояву професійних здібностей під час карантинних обмежень.

Дев`яте питання стосувалося рівня методичного підходу вчителя до викладання. 52 \% школярів вважають, що їх вчитель відпрацював на високому педагогічному рівні, а 48 \% учнів зазначили низькі показники. Фактично половина опитаних повністю задоволенні педагогічним рівнем викладання вчителя, інші не відчули достатнього прояву педагогічної складової. Отримані результати визначили потужну слабкість викладання, адже кожен 
2-гий учень незадоволений ставленням вчителя до організації і проведення занять фізичної культури під час дистанційного навчання.

У десятому питанні стосовно «небайдужості вчителя до організації проведення уроків фізичної культури під час дистанційного навчання» майже 62 \% респондентів вказали на позитивну орієнтацію вчителя до організації та проведення уроків фізичної культури, а близько 38 \% надали невизначену або негативну оцінку. Це свідчить, що школярі помічають і аналізують старанність вчителя до викладання практичного уроку в складних умовах, що склалися.

Одинадцяте питання стосовно «відповідності проведення уроків фізичної культури із запитами учня під час дистанційного навчання» відкрило блок питань стосовно організації навчання. Відповідями респондентів (59\%) зазначено теперішню неповноцінність дистанційного навчання, що є негативним фактором процесу ефективного вивчення предмету фізичної культури. Лише 23 \% учнів повністю впевнені у задоволенні власних запитів і 18 \% вважають - «скоріше так». Результати одинадцятого питання надали негативну оцінку і виокремили малоефективність системи дистанційного навчання на уроках фізичної культури, адже у порівнянні зі звичними формами організації та проведення уроків програють і не сприяють необхідному гармонійному розвитку.

у дванадцятому питанні розкрито «доступність, комфортність, ефективність, продуктивність і раціональність уроків, які проводить вчитель дистанційно». Важливо зазначити, що близько 30 \% учнів мали чітку позицію на рахунок відповідних вимог і мають позитивний відгук про уроки проведені їх вчителем у той час, як близько 13 \% вважають - «скоріше так», проте, переважна більшість 57 \% респондентів оцінили ознаки результативності уроку негативно. Доцільно підкреслити, що раціональна взаємодія вчителя та учня втрачається під час проведення уроків онлайн, як наслідок, заняття мають низький рівень ефективності.

Зміст тринадцятого питання стосовно необхідності проведення уроку фізичної культури за допомогою онлайн-конференцій, постійного спілкування, творчих та навчальних завдань підтвердив важливість взаємодії вчитель-учень. Позитивне схвалення мають лише 37 \%, що перехресно підтверджує зміст результатів 5-го питання анкети, 63 \% школярів відповіли негативно.

У чотирнадцятому питанні про «відчуття повноцінної присутності на уроці фізичної культури, навіть, при виконанні певних фізичних вправ під час дистанційного навчання» лише близько $31 \%$ учнів надали позитивну відповідь, близько 69 \% респондентів відповіли «категорично ні, скоріше ні, важко відповісти». Практичний предмет у форматі дистанційного викладання, маючи значну кількість вимог та правил до організації освітнього процесу, на сьогодні їм не відповідає, що негативно відображається на авторитеті галузі фізичної культури і спорту.

П`ятнадцяте питання дозволило визначити спроможність конкурування уроків дистанційного формату з уроками, проведеними у спортивному залі. Закономірно, що лише близько 22 \% школярів відповіли позитивним чином (є підстави вважати, що це учні, кому пощастило працювати з висококваліфікованими вчителями, які швидко зорієнтувалися в особливостях онлайн-технологій), а інші 78 \% респондентів визначились в бік звичної форми навчання. Доцільно узагальнити негативні сторони: втрача- ється взаємодія, мотивація, повноцінність відчуття уроку, нівелюється авторитет вчителя через оголені недоліки викладання і урок перетворюється у формальність.

Шістнадцяте питання про проведення уроків фізичної культури за розкладом під час дистанційного навчання відкрило блок питань стосовно якості навчання, викладання та сприйняття. Важливо, що більшість близько 60 \% респондентів надали позитивні відповіді. Отримані результати дають певну надію, що більшість фахівців галузі фізичної культури не втратили інтерес до якісної педагогічної діяльності й старанно намагалися уникнути певних недоліків у проведенні уроків фізичної культури під час дистанційного навчання.

У сімнадцятому питанні проаналізовано відповідність викладання, сприйняття завдань та навчання фізичним вправам, запропонованим вчителем під час дистанційного навчання у порівнянні зі звичним проведенням уроків у спортивному залі. Близько 39 \% позитивних і 61 \% негативних відгуків - закономірні результати несприйняття практичного предмету дистанційно основними учасниками освітнього процесу - учнями.

Вісімнадцяте питання надало змогу з'ясувати можливості гармонійної заміни уроків у спортивній залі з учителем на уроки онлайн під час дистанційного навчання. 79 \% школярів визначили, що урок фізичної культури у спортивній залі під час очного навчання $€$ незамінними і навіть повноцінно безальтернативними під час ситуації карантинних обмежень, яка склалась. $Є$ підстави зауважити, що галузь фізичної культури і спорту є непідготовленою до таких ситуацій, а очне навчання у школі не змогло надихнути учнів і стимулювати до самовдосконалення.

Дев`ятнадцятим питанням підведено підсумок щодо отримання учнями однакових знань, можливостей фізичного розвитку, психологічних якостей та задоволення власних потреб від проведення уроків фізичної культури дистанційно. Відповіді 32 \% досліджуваних учнів склали позитивний результат, проте негативну оцінку надали 68 \% школярів. Доречно охарактеризувати загальний стан питання так - дистанційне навчання у практичному предметі є недопрацьованим і урок фізичної культури не може задовольнити потреби учнів у необхідному фізичному та духовному розвитку.

Заключне двадцяте питання анкети про рівень задоволеності викладанням уроків фізичної культури дистанційно дозволив обґрунтувати отримані результати в цілому: 48 \% школярів задоволені викладанням ( дійсно високий рівень професіоналізму вчителя, або через невідповідальне ставлення до власного здоров'я учням подобається формальність, байдужість і непрофесіоналізм вчителя); 52 \% респондентів не задоволені викладанням (не подобається відповідальність і якісно-професійний підхід вчителя до предмету, дійсно низький рівень начального процесу через байдуже ставлення наставника).

Останнє питання анкети (відкрите) запропоновано респондентам для з'ясування їх бачення шляхів покращення, адже власний досвід дозволяє порівняти і проаналізувати проблемні питання, об'єднати зусилля у створенні сучасних підходів до викладання практичного уроку в умовах карантину, що вже мають тривалий термін застосування і на перспективу мають бути покращеними для ефективності освітнього процесу. Розглянувши й узагальнивши відповіді на питання очевидно, що дистанційне навчання викликало низку негативних суджень і наслідків через не- 


\section{СЛОБОЖАНСЬКИЙ НАУКОВО-СПОРТИВНИЙ ВІСНИК}

гнучкість і неготовність системи швидко адаптуватись у складній ситуації, що виникла в Україні і світі.

\section{Висновки / Дискусія}

Отриманими результатами дослідження підтверджено актуальність розглянутих питань, адже спеціалістами галузі фізичної культури і спорту зазначено потребу у вивченні підходів до проведення занять фізичним вихованням через високу вірогідність повторення вимушеного забезпечення якості освітнього процесу в умовах карантинних обмежень в майбутньому [5, 9]. Вивчення науково-методичної літератури і інформативних джерел мережі інтернет надало підстави узагальнити необхідність якісної підготовки фахівців галузі фізичної культури і спорту до форм дистанційного викладання з урахуванням необхідності змін у ставленні всіх учасників освітнього процесу до якості навчання, форм, методів і засобів його організації $[2,4,11]$.

У доступній літературі не знайдено інформації стосовно визначення рівня задоволеності проведенням уроків фізичної культури школярів у дистанційному форматі. За результатами сформованої анкети і організованого анкетування 95 школярів різних закладів середньої освіти міст Києва і Білої Церкви визначено, що проведення уроків фізичної культури носить переважно формальний характер, є малоефективним і має зазнати кардинальних змін, на сьогодні не може бути альтернативою практичним заняттям в спортивній залі, а лише їх продуманим доповненням в системі змішаного навчання. Оцінка задоволеності учнями проведенням уроків фізичної культури в різних школах надала обґрунтовані підстави зрозуміти, які саме проблеми має організація дистанційних занять, яких змін у підходах потребує освітня галузь і безпосередньо фахівці фізичного виховання і що саме доцільно додати в організації проведення уроків фізичної культури під час дистанційного навчання задля успішної, ефективної і продуктивної відповідності вимогам та потребам сучасного школяра.

Результати дослідження свідчать, що рівень задоволеності учнів уроками фізичної культури в умовах карантинних обмежень, викликаних пандемією, напряму залежить від зацікавленості, відповідальності, професіоналізму наставника та активного зворотного зв'язку вчитель-учень, що підтверджено думками впливових фахівців [2, 4, 5, 9-11]. Відсутність зазначених складових нівелює гармонійний розвиток школяра [1] і провокує негативні наслідки [6]. З'ясована переважна зацікавленість учнів у отриманні знань, вмінь та навичок, носіями яких є вчитель фізичної культури.

Перспективи подальших досліджень полягають у подальшому визначенні підходів і методів організації та проведення занять під час дистанційного навчання з метою з'ясування помилок та синтезу переваг для ефективного вивчення предмету фізична культура в період карантинних обмежень навчального процесу.

Конфлікт інтересів. Автори заявляють, що відсутній конфлікт інтересів, який може сприйматись таким, що може завдати шкоди неупередженості статті.

Джерела фінансування. Ця стаття не отримала фінансової підтримки від державної, громадської або комерційної організації.

\section{Список посилань}

1. Вергуш О. М. (2009), «Формування здорового способу життя школярів засобами фізичного виховання», Фізичне виховання, спорт і здоров'я людини, Вісник Кам'янець-Подільського національного університету імені Івана Огієнка.. Том 2. Випуск 2. Кам'янець-Подільський. С. 150-153.

2. Воротникова І. П,. Чайковська Н. В. (2020), Дистанційне навчання: виклики, результати та перспективи. Порадник. 3 досвіду роботи освітян міста Києва: навч.-метод. посіб. Київ. ун-т ім. Б. Грінченка, 456 с.

3. Кудрявцева Г., Шишкин В. (2020), Коронавирус апокалипсиса. СПб,: Изд-во ВВМ, 60 с.

4. Москаленко Н., Яковенко А., Овчаренко С., Сидорчук Т. (2020), «Організаційно-педагогічні умови забезпечення якості фізичного виховання школярів», Слобожанський науково-спортивний вісник. № 2(76), С. 7-23, doi:10.15391/snsv.2020-2.001

5. Мунтян В. С. (2016), «Імплементація дистанційного навчання як умова підвищення ефективності фізичного виховання», Науковий часопис НПУ імені М.П. Драгоманова, Випуск ЗК 2 (71), С. 212-215.

6. Хорощак К. (2020), Симптоми, наслідки, імунітет, вакцини та інше: що світ знає про COVID-19. Підсумки-2020. Режим доступу: https://life.pravda.com.ua/health/2020/12/28/243513/

7. Bulatova M., Kucheriavyi O., Ermolova V., Yarmoliuk O. (2019), «Distance-pedagogical technologies in Olympic education for schoolchildren», Journal of Physical Education and Sport. Vol.19 (4), Art 378, pp. 2497-2503.

8. COVID-19 Dashboard by the Center for Systems Science and Engineering (CSSE) at Johns Hopkins University (JHU). Peжим доступу: https://gisanddata.maps.arcgis.com/apps/opsdashboard/index.html\#/bda7594740fd40299423467b48e9ecf6

9. Osipov A. Y., Kudryavtsev M. D., Galimova A. G., Plotnikova I. I., \& Skurikhina N. V. (2020), «How can Distance Learning be Used in the Physical Education of Students», Revista Romaneasca Pentru Educatie Multidimensionala, 12(2Sup1), 77-85. https://doi. org/10.18662/rrem/12.2Sup1/292

10. Regina Celia A. Silva, Vera Lucia de F. F. e Silva, Andrŭ Pontes Silva (2019), «Distance learning for teaching in physical education. Universidade Federal do Maranhro. Motriz», Revista de Educазго Fнsica 25 (1). DOI: 10.1590/s1980-6574201900010002

11. Rembach O., Liybich O., Antonenko M., Kovalenko V., \& Valieiev R. (2019), «University students` satisfaction: The impact of computermediated blended learning», Revista Romвnească pentru Educaţie Multidimensională, 11 (4S1), 221-241. DOI: 10.18662/rrem/186.

Стаття надійшла до редакції: 20.01.2021 р.

Опубліковано: 22.02.2021 p.

Аннотация. Николай Шаповалов, Руслана Сушко. Особенности организации дистанционного обучения как формы проведения уроков физической культуры. Цель: исследовать современные подходи кдистанционномуобучению на уроках физической культуры в школах. Материал и методы: применен анализ научно-методической литературы и информативных данных сети Интернет; анкетирование с помощью google-формы; методы математической статистики, организовано анкетирование 95ти учеников среднеобразовательных школ городов Киева и Белой Церкви. Результаты: проанализировано современное состояние вопроса относительно организации и проведения дистанционного обучения. Определено, что организация уроков физи- 
ческой культуры носит преимущественно формальный характер, является малоэффективной и должна претерпеть кардинальные изменения, не может быть альтернативой практическим занятиям в спортивном зале, а лишь их дополнением. Оценка удовлетворенности учениками проведением уроков физической культуры предоставила обоснования понять проблемы организации дистанционных уроков, необходимость изменений в подходах к обучению специалистов физического воспитания, что именно целесообразно прибавить в организации уроков физической культуры во время дистанционных занятий для эффективного соответствия требованиям потребностям современного школьника. Выводы: выявлено, что уровень удовлетворенности учеников проведением уроков физической культуры в условиях карантинных ограничений напрямую зависит от заинтересованности, ответственности, профессионализма наставника и активной обратной связи ученик-учитель. Отсутствие указанных составляющих нивелирует гармоничное развитие школьника и провоцирует негативные последствия. Выяснена преимущественная заинтересованность учеников в получении знаний, умений и навыков, носителями которых являются учителя физической культуры.

Ключевые слова: физическая культура, урок, дистанционное обучение, коронавирус.

Abstract. Mykola Shapovalov, Ruslana Sushko. Peculiarities of the online teaching process organisation as a form of physical training lessons. Purpose: to investigate modern approaches to the online teaching process during physical training lessons at schools. Material and methods: analysis of scientific and methodological literature along with Internet informative data; questionnaire using google-forms; methods of mathematical statistics were applied, a survey of 95 secondary schools pupils in Kyiv and Bila Tserkva cities was organised. Results: current state of this issue regarding the online teaching process organisation was analysed. It has been determined that the physical training lessons organisation has predominantly a formal nature, it is ineffective and must undergo fundamental changes; it cannot be an alternative to practical training in the gym, only as its addition. Assessment of pupils' satisfaction with physical training lessons provided justification for understanding the problems of online lessons organisation, the necessity for changes in approaches to teaching of physical education specialists, what exactly it would make sense to add to the physical training lessons organisation during online lessons in order to meet effectively the requirements of a modern student needs. Conclusions: it was revealed that the level of satisfaction with physical training lessons among students in conditions of lockdown restrictions depends directly on the interest, responsibility, professionalism of the mentor and active student-teacher feedback. The absence of the components mentioned before neutralises the harmonious development of a pupil and provokes negative consequences. The predominant pupils' interest to obtain knowledge, skills and abilities provided by physical training teachers was specified.

Keywords: physical education, lesson, distance learning, coronavirus.

\section{References}

1. Verhush, O. M. (2009), «Formuvannia zdorovoho sposobu zhyttia shkoliariv zasobamy fizychnoho vykhovannia», Visnyk Kamianets-Podilskoho natsionalnoho universytetu imeni Ivana Ohiienka. Fizychne vykhovannia, sport i zdorovia liudyny, Tom 2. Vypusk 2. Kamianets-Podilskyi. pp. 150-153. (in Ukr.).

2. Vorotnykova, I. P,. Chaikovska, N. V. (2020), Dystantsiine navchannia: vyklyky, rezultaty ta perspektyvy. Poradnyk. Z dosvidu roboty osvitian mista Kyieva: navch.-metod. posib. Kyiv. un-t im. B. Hrinchenka, 456 p. (in Ukr.).

3. Kudriavtseva, H., Shyshkyn, V. (2020), Koronavyrus apokalypsysa. SPb: Yzd-vo VVM, 60 p. (in Ukr.).

4. Moskalenko, N., Yakovenko, A., Ovcharenko, S., Sydorchuk, T. (2020), «Orhanizatsiino-pedahohichni umovy zabezpechennia yakosti fizychnoho vykhovannia shkoliariv», Slobozhanskyi naukovo-sportyvnyi visnyk, № 2(76), pp. 7-23, doi:10.15391/snsv.2020-2.001 (in Ukr.).

5. Muntian, V. S. (2016), «Implementatsiia dystantsiinoho navchannia yak umova pidvyshchennia efektyvnosti fizychnoho vykhovannia», Naukovyi chasopys NPU imeni M.P. Drahomanova, Vypusk 3K 2 (71), pp. 212-215. (in Ukr.).

6. Khoroshchak, K. (2020), Symptomy, naslidky, imunitet, vaktsyny ta inshe: shcho svit znaie pro COVID-19. Pidsumky-2020. URL: https://life.pravda.com.ua/health/2020/12/28/243513/ (in Ukr.).

7. Bulatova, M., Kucheriavyi, O., Ermolova, V., Yarmoliuk, O. (2019, «Distance-pedagogical technologies in Olympic education for schoolchildren", Journal of Physical Education and Sport, Vol.19 (4), Art 378, pp. 2497-2503. DOI: 10.7752/jpes.2019.04378

8. COVID-19 Dashboard by the Center for Systems Science and Engineering (CSSE) at Johns Hopkins University (JHU). URL: https://gisanddata.maps.arcgis.com/apps/opsdashboard/index.html\#/bda7594740fd40299423467b48e9ecf6

9. Osipov, A. Y., Kudryavtsev, M. D., Galimova, A. G., Plotnikova, I. I., \& Skurikhina, N. V. (2020). «How can Distance Learning be Used in the Physical Education of Students», Revista Romaneasca Pentru Educatie Multidimensionala, 12(2Sup1), pp.77-85. https:// doi.org/10.18662/rrem/12.2Sup1/292

10. Regina Celia A. Silva, Vera Lucia de F. F. e Silva, Andrŭ Pontes Silva (2019), «Distance learning for teaching in physical education. Universidade Federal do Maranhro. Motriz», Revista de Educaзго Fнsica 25 (1). DOI: 10.1590/s1980-6574201900010002

11. Rembach, O., Liybich, O., Antonenko, M., Kovalenko, V., \& Valieiev, R. (2019), «University students` satisfaction: The impact of computermediated blended learning», Revista Romвnească pentru Educaţie Multidimensională, 11 (4S1), pp. 221-241. DOI: 10.18662/rrem/186.

Received: 20.01.2021.

Published: 22.02.2021.

\section{Відомості про авторів / Information about the Authors}

Шаповалов Микола Валерійович: Київський університет імені Бориса Грінченка: м. Київ, вул. Маршала Тимошенка 13-Б. Шаповалов Николай Валерьевич: Киевский университет имени Бориса Гринченко: Г. Киев, ул. Маршала Тимошенка 13-Б. Mykola Shapovalov: Borys Grinchenko Kyiv University: Kyiv, Ukraine. str. Marshala Tymoshenko, 13-B.

ORCID.ORG/000-0002-0391-2676

E-mail: mvshapovalov.fzfvs18@kubg.edu.ua

Сушко Руслана Олександрівна: д.фіз.вих., доцент, Київський університет імені Бориса Грінченка: м. Київ, вул. Маршала Тимошенка 13-Б.

Сушко Руслана Александровна: д.физ.восп., доцент, Киевский университет имени Бориса Гринченко: г. Киев, ул. Маршала Тимошенко 13-Б.

Ruslana Sushko: Doctor of Science (Physical Education and Sport), assistant professor, Borys Grinchenko Kyiv University: Kyiv, Ukraine. str. Marshala Tymoshenko 13-B.

ORCID.ORG/0000-0003-3256-4444

E-mail: r.sushko@kubg.edu.ua 